\title{
41. Gastronomi metinleri çevirisinin bir alt alanı olarak yemek tarifi çevirileri
}

\section{Sevda PEKCOȘKUN GÜNER ${ }^{1}$}

APA: Pekcoşkun Güner, S. (2021). Gastronomi metinleri çevirisinin bir alt alanı olarak yemek tarifi çevirileri. RumeliDE Dil ve Edebiyat Araştırmaları Dergisi, (Ö9), 506-524. DOI: 10.29000/rumelide.983910.

\section{$\ddot{0} \mathbf{z}$}

Çeviribilimde uygulamalı bir alan olarak kabul edilen gastronomi metinleri çevirisi, kendi çeviri işlemlerine, örüntülerine ve stratejilerine sahip olan bir inceleme alanıdır. Gastronomi metinleri, yemek tarifleri veya restoran menüleri yanında, yemek blogları, web siteleri, yemek dergileri, yerel ve uluslararası mutfaklar, gastronomi haberleri, gıda pazarlaması ile aşçılık ve yemekle ilgili diğer tüm metin gruplarını içerir. Bu metinlerin kendi terminolojik özellikleri, alana özgü dili, metinsel ve anlamsal bileşenleri vardır. Bu nedenle, gastronomi metinleri çevirisi, özel alan terminolojisi ve kültüre özgü unsurlar açısından karmaşık ve zorlu bir alan haline gelmektedir. Kaynak kültürün tanıtılmasına katkıda bulunduğundan, bu metinlerin çevirisi gastronomi turizminin gelişmesinde önemli bir rol oynamaktadır. Tutarlı ve akıcı bir çeviri gerçekleştirerek, erek metnin alıcı kitle tarafından benimsenmesini sağlamak amacıyla, gastronomi metinlerinin çeviri sürecinde işlevsel bir yaklaşım uygulanması gerekir. Bu bağlamda, gastronomi metinleri çevirisi, kaynak odaklı ve sözcügü sözcüğüne çeviri yaklaşımının ötesine geçmektedir. Yemek tarifleri, gastronomi çalıșmalarında bir metin türü olarak kabul edilir. Günümüz dünyasında, işitsel, görsel ve dilsel modlar da dahil olmak üzere, birçok yemek tarifi, dijital biçimlerde, çok modlu metinler olarak tasarlanmıştır. Yemek tarifi çevirilerinde karşılaşılan başlıca zorluklar, özel alan terminolojisi, yemek adları, kültüre özgü unsurlar, ölçü birimleri, bölgesel tatlar ve malzemelerin çevirisi olarak sıralanabilir. Bu çalışmada, çeviriye ilişkin konular, Türkçe-İngilizce dil çiftinde açıklanmış ve örneklendirilmiş olup, seçilen örneklerde Türkçe kaynak dil olarak yer almıştır. Gastronomi alanında metin türlerini belirlemek, yemek tariflerini metinsel özellikleri açısından incelemek ve yemek tarifi çevirisi sürecinde karşılaşılabilecek çeviri sorunları ve bu sorunlara yönelik olarak uygulanabilecek yöntemleri saptamak bu çalışmanın temel amaçlarını oluşturmaktadır.

Anahtar kelimeler: Gastronomi Çevirisi, Yemek Tarifi Çevirisi, Çeviri Çalışmaları, Gastronomi Metinleri

\section{Translation of recipes as a subfield of gastronomic translation}

\begin{abstract}
As an applied field of Translation Studies, gastronomic translation is a particular subject of study which includes its own translation procedures, patterns, and strategies. Gastronomic texts do not only contain cooking recipes or restaurant menus, but also cooking blogs, websites, food magazines, local and international cuisines, culinary news, food marketing, and other relevant text groups about cookery and food. Texts on gastronomy have their own terminological features, domain-specific language, textual and semantic conventions. Therefore, gastronomic translation becomes a complicated and challenging field in terms of specialized terminology and culture-specific items. As gastronomic translation contributes to the introduction of the source culture, it relatively plays an important role in the development of culinary tourism. Gastronomic translation requires a functional approach that leads to a coherent and fluent
\end{abstract}

1 Dr. Öğr. Üyesi., Kırklareli Üniversitesi, Fen Edebiyat Fakültesi, İngilizce Mütercim Tercümanlık Bölümü (Kırklareli, Türkiye) sevda.pekcoskun@gmail.com, ORCID ID: 0000-0003-2750-3217 [Araştırma makalesi, Makale kayıt tarihi: 25.07.2021-kabul tarihi: 20.08.2021; DOI: 10.29000/rumelide.983910]

Adres

RumeliDE Dil ve Edebiyat Araştırmaları Dergisi Osmanağa Mahallesi, Mürver Çiçeği Sokak, No:14/8 Kadıköy - ISTANBUL / TÜRKIYE 34714 e-posta: editor@rumelide.com tel: +90 $5057958124,+902167730616$
Address

RumeliDE Journal of Language and Literature Studies

Osmanağa Mahallesi, Mürver Çiçeği Sokak, No:14/8

Kadıköy - ISTANBUL / TURKEY 34714

e-mail: editor@rumelide.com,

phone: +90 5057958124, +90 2167730616 
translation to be adapted by target audience. In this context, gastronomic translation goes beyond source-oriented and literal translation approach. Cooking recipes can be accepted as a specific text type in gastronomy studies. In today's world, including aural, visual, and linguistic modes, many recipes are designed as multimodal texts which are available in digital formats. Main challenges of recipe translation may be listed as the translation of specialized terminology, food names, culture-specific items, measurement units, regional tastes, and flavors. In this study, translation issues are defined and exemplified in Turkish-English language pair, while the former is the source language. The purposes of this study are identifying gastronomic text types; examining cooking recipes in terms of textual characteristics; and describing problematic issues to be faced in the process of recipe translation, and translation procedures to be used.

Keywords: Gastronomic translation, Recipe Translation, Translation Studies, Gastronomic Texts

\section{Giriş}

Abraham Maslow tarafından ortaya atılan ihtiyaçlar hiyerarşisine göre, bireyin ihtiyaçları beş temel kategoride toplanabilir: fizyolojik, güvenlik, sevgi, saygı ve kendini gerçekleştirme. Maslow’a göre, fizyolojik ihtiyaçlar, bu hiyerarşinin en temel unsurlarıdır. Bir kişinin birden fazla kategorinin kapsamına giren ihtiyaçları varsa, muhtemelen ilk önce fizyolojik ihtiyaçlarını karşılamaya çalışır. Örneğin; birisi çok açsa, yemek dışında başka bir şeye odaklanması zordur (Maslow, 1943). Bireyler, yaşamlarını sürdürmek için beslenmeye gereksinim duyar. Çağlar boyunca, insanlar yemek yapmış ve hazırladıkları yemekleri tüketmişlerdir. Ancak, zaman içinde malzemeler çeşitlendikçe, bireyler yalnızca "karnını doyurmak" için yemek yapmamış; yemek yaparak gelir elde etmeye de başlamışlardır. "Yaşamak için yemek yeme" ifadesi, yaşamın devamlılığı için beslenmeye duyulan gereksinime işaret eder. Oysa günümüzde bu düşünce "yemek için yaşama" düsturuna evrilmiş, insanlar kendilerini daha iyi hissetmek için yemek hazırlamaya başlamışlardır. Farklı lezzetler birer cazibe merkezi durumuna gelmiş; kentlere, yörelere ve bölgelere özgü yemek kültürleri oluşmaya başlamıştır. Gastronomi kavramı da "zevk için beslenme" düşüncesinden ortaya çıkmıştır.

Fransızca kökenli (gastronomie) bir sözcük olan "gastronomi”, Türk Dil Kurumu'nun Güncel Türkçe Sözlügünde, "yemeği iyi yeme merakı" ve "sağlığa uygun, iyi düzenlenmiş, hoş ve lezzetli mutfak, yemek düzeni ve sistemi” olarak tanımlanmıştır². Collins Çevrimiçi Sözlükte3 ise, gastronomi, "iyi yemeklerin hazırlanmasını ve takdir edilmesini kapsayan etkinlik ve bilgi", "iyi yeme sanatı," ve "belli bir bölgeye özgü mutfak türü," olarak tanımlanmıştır4. Gastronomi kavramının kültürle ilişkisi yadsınamaz. Gastronomi, toplumsal, ekonomik ve coğrafi bağlamda içecekleri de kapsayacak şekilde mutfak ve yeme içme geleneklerinin incelenmesi ve anlaşılması amacıyla yapılan çalışmaları içerir. Yemek kavramı günlük yaşamın, geleneklerin, kültürün ve medeniyetin merkezinde yer alır (Gillespie, 2001: xi). Ülke ve bölge mutfakları (Türk mutfağı, Akdeniz mutfağı vb.), ilgili coğrafi alanda yetişen malzemeleri sıklıkla içeren tatlarla karakterize olup, yöre insanının kültürel özelliklerinin katkısıyla şekillenir. Bölgenin gastronomi kültürüne ilişkin fikirler veren yerel mutfaklar, söz konusu yörenin tanıtılmasında da önemli rol oynar.

Gastronomi ve gastronomi kültürü, yakın zamana kadar bireylerin çoğunluğunun ilgi alanına girmemekte; gastronomi kültürünün aktarımı, büyük ölçüde, küçük ama toplum içinde öne çıkan "elitlerle" sınırlandırılmakta, yalnızca bu grupla ilişkilendirilmekte ve bu grup tarafından teşvik edilmekteydi

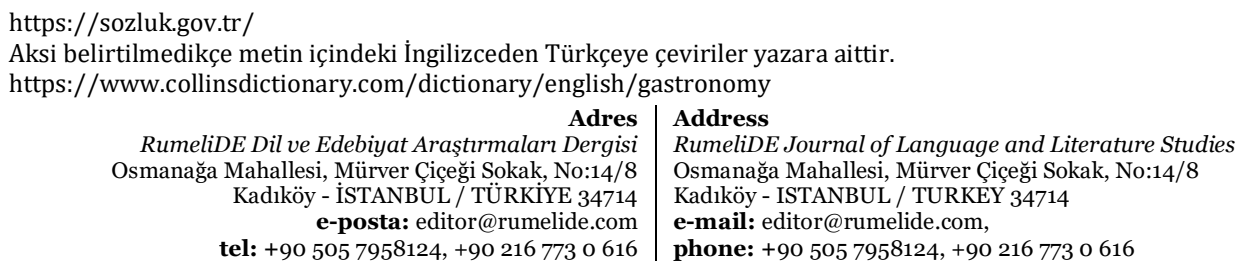


(Gillespie, 2001: 5). Ancak günümüzde gastronomi kültürü sadece kısıtlı bir zümrenin ya da gurmelerin ilgi alanı olmaktan çıkmıș, toplumun diğer kesimlerinde de ilgi ve merak uyandırmaya başlamıştır. Bu durumun en önemli sebepleri arasında küreselleşme ve dijital çağın toplum hayatına etkileri sayılabilir.

Aşçllık temalı TV şovları ve programları tüm dünyada oldukça popülerdir. Örneğin; İngiltere kökenli bir aşçlık yarışması olan Masterchef in Türkiye uyarlaması haftada en az üç gün olmak üzere yayınlanmaktadır. Gastronomiye olan ilgi, çeviri ihtiyacını da beraberinde getirmiștir. Gastronomi alanında tematik yayın yapan TV kanalları sayısı da son yıllarda artış göstermiştir. Örneğin; 24Kitchen Türkiye'de 24 saat yayın yapan bir yemek kanalıdır ve yayın dili Türkçedir. Bu kanalda, yabancı yemek programlarına ait içerikler Türkçeye çevrilmekte; programlar Türkçe dublajla yayınlanmaktadır. Çeviri içeriğe sahip birkaç örnek vermek gerekirse, Martha'nın Firını (en. Martha Bakes) ve Gordon Ramsay ile 24 Saatte Devrim (en. Gordon Ramsay's 24 Hours to Hell and Back) programlarını saymak mümkündür. Kanal web sayfasında da gastronomiye ilişkin yazılar ile Türk ve dünya mutfaklarına özgü yemek tarifleri yer almaktadır5. TV kanalları, web sayfaları, mobil uygulamalar gibi dijital içeriklerle gastronomi bilgisi toplumun tüm katmanlarına ulaşabilmektedir.

Küreselleşme ile yemek ve mutfak malzemelerinin çeşitliliği ve erişilebilirliği artmış, yalnızca insanların değil, yemeğin de dolaşımı hız kazanmıştır. Örneğin; günümüzde Latin Amerika coğrafyasına özgü bir meyve ülkemizde rahatlıkla bulunabilmekte, bu malzeme kullanılarak gerek geleneksel tatlara yeni bir yorum getirilebilmekte, gerekse de söz konusu meyvenin temel bir malzeme olarak içeriğinde yer aldığı yabancı mutfaklara ait değişik tatlar denenebilmektedir. Böylece farklı mutfak kültürleri birbirleriyle yakınlaşmakta ve iç içe geçmektedir.

20. yüzyılın ortalarında başlayan bilgi çağı ya da dijital çă̆, dünyanın farklı yerlerinde bulunan kişilerin büyük miktarlarda bilgiye bilgisayar sistemleri ve internet olanakları sayesinde erişebilmesini mümkün kılmıştır. Dijital okuryazar olan bireyler, istedikleri veriye farklı ortamlar (dizüstü bilgisayar, tablet, akıllı telefon vb.) üzerinden tek bir adımla kısa sürede ulaşabilmektedir. Böylece dijital ortamda sınırlar ortadan kalkmış, bununla bağlantılı olarak, bilginin dolaşımı ve yayılımı kolaylaşmıştır. Dijital çağın getirdiği olanakları kullanarak, bireyler bir yandan yaşadıkları bölgeye ait yerel mutfak kültürüne ilişkin bilgiler edinebilmekte; diğer yandan ise coğrafi olarak kendilerine uzak olan bölgelere özgü mutfakları ve yeme içme geleneklerini tanımaktadır. Örneğin; "Japon mutfağı" söz öbeğiyle, internet üzerinden aramasını gerçekleştiren bir kişi, ilgili mutfakta kullanılan temel malzemeler, Japonların yeme içme alışkanlıkları, geleneksel Japon yemekleri, Japon mutfağına özgü yemek tarifleri ve ünlü restoranlar gibi birçok bilgiye erişebilir.

Çeviri farklı gastronomi kültürlerinin tanıtılmasında önemli bir rol üstlenmektedir. Çeviri etkinliği, dilsel aktarımın yanında kültürel aktarımı da içerir. Farklı kültürler arasında bir köprü olma görevi üstlenen çevirmen, kültürlerin tanıtılması ve birbirleriyle yakınlaşmasına aracılık eder. Gastronomi de kültürden bağımsız bir kavram olarak düşünülemeyeceğinden, çeviri etkinliği gastronomi metinlerinin farklı dillere aktarımını sağlayan önemli bir bileşendir.

Bu bağlamda gastronomi turizminden de söz etmek gerekmektedir. Farklı erek dil karşılıklarının ortaya atılması ve dolayısıyla terminoloji alanında terim standardizasyonunun tam olarak sağlanamaması nedeniyle, "gastronomi turizmi" ifadesi yerine, "gastro turizm", "gastronomik turizm", "yeme-içme turizmi", "yemek turizmi", "mutfak turizmi", "gastronomi ve şarap turizmi", "aşçllk turizmi", "gurme turizmi", "tat turizmi", "beslenme turizmi", "gıda turizmi", "yerel mutfak turizmi", "yiyecek ve şarap turizmi" ve "yiyecek

https://www.24kitchen.com.tr/

RumeliDE Dil ve Edebiyat Araştırmaları Dergisi Osmanağa Mahallesi, Mürver Çiçeği Sokak, No:14/8 Kadıköy - ISTANBUL / TÜRKIYE 34714 e-posta: editor@rumelide.com tel: +90 $5057958124,+902167730616$
Address

RumeliDE Journal of Language and Literature Studies

Osmanağa Mahallesi, Mürver Çiçeği Sokak, No:14/8

Kadıköy - ISTANBUL / TURKEY 34714

e-mail: editor@rumelide.com,

phone: +90 $5057958124,+902167730616$ 
turizmi" ifadeleri de kullanılmaktadır. Gastronomi turizmi yerli ya da yabancı turistin kültürel ve yerel tatları, kokuları, yiyecek ve içecekleri deneyimleyebildiği bir turizm çeşididir. Gastronomi turizmi, bir bölgenin kültürel kimliğini ve mirasını da yansıtarak, ilgili bölgeye turizmde rekabet avantajı sunar (Yücel Güngör, 2020: 19).

Çeviri etkinliği, gastronomi turizminin ayrılmaz bir parçasıdır. Yabancı turistler, ziyaret ettikleri ülke ya da bölgede mümkün olduğunca kendi dillerinde hizmet almak isterler. Turistik alanlarda yer alan restoranların çok dilli olarak tasarlanmış menüleri bu duruma örnek olarak verilebilir. Ancak, gastronomi turizmi içinde çeviri etkinliğinin kapsamı restoran menüleriyle sinırlandırılamaz. Ziyaret edilen yörenin meşhur tatlarının tanıtılması, bölgeye özgü yiyecek ve içeceklere ilişkin bilgi verilmesi, bu yiyecek ve içeceklerin tarihçesi ve kültürel bağlamına yönelik bilgilendirme yapılması, yöreye ait tatların tariflerinin verilmesi gibi etkinlikler çeviri işlemleriyle doğrudan bağlantılıdır. Ayrıca, yazılı çeviri yanında, sözlü çeviri de gastronomi turizminin gelişimi, gastronomi kültürünün tanıtımı ve yayılımda oldukça önemlidir. Örneğin; yabancı turistlere yörede yer alan bir şarap mahzeni ya da zeytinyă̆ı üretim tesisi gezdirilirken, çevirmen gerek yazılı metinden sözlü çeviri gerekse de ikili görüşme çevirisi gerçekleştirerek gastronomi turizminde görev alır.

Gastronomi metinleri çevirisi, yemek ve beslenme ile ilgili tüm alt metin gruplarına ilişkin çeviri etkinliğini içerir. Bu metinlerden bazıları restoran menüleri ve yemek tarifleri ile pişirme teknikleri, mutfak kültürü ve tarihine ilişkin metinlerdir. Gastronomi metinleri, teknik metinler gibi alana özgü dil ve terminolojiye sahiptir. Aynı zamanda söz konusu metinlerde sıklıkla kültürel unsurlarla karşılaşmak mümkündür. Çeviri sürecinde karşılaşılan temel sorunlardan biri kültüre özgü ifadelerin erek dile aktarılmasıdır. Kaynak kültüre özgü bir yiyecek bileşeninin ya da yemek yapımında kullanılacak malzemenin erek kültürde var olmaması ya da erek kitle tarafından bilinmemesi durumunda nasıl bir çeviri stratejisi izleneceği ve çeviri işlemi gerçekleştirileceğine ilişskin kararların doğru bir şekilde alınması, erek metnin kabul edilebilirlik düzeyini de etkileyecektir. İşlevsel bir erek metnin üretilebilmesi için gastronomi metinlerinin çeviribilimsel bir bakış açısıyla incelenmesi ve metin geleneklerinin belirlenmesi, çeviri sürecinde alınacak kararların ve uygulanabilecek yöntemlerin saptanmasında yol gösterici olabilecektir.

Günümüzde basılı dilsel malzemeler kullanılmaya devam etse de bilgi akışı çoğunlukla elektronik ortamda ve dijital metinler aracılığıyla gerçekleşmektedir. Gastronomi alanında da durum farklı değildir. Yemek blogları, web siteleri ve sosyal medya aracılığıyla çeşitli alanlardan derlenen gastronomi bilgisi kullanıcıyla buluşmaktadır. Bu noktada, çok modlu çeviri (multimodal translation) konusu gündeme gelmektedir. Dijital metinler çoğunlukla çok modludur ve bu nedenle göstergelerarası çeviri ya da işitsel-görsel çevirinin de çeviri sürecine dahil edilebileceği söylenebilir. Dilsel içeriğin videolar ve görsel içerikle desteklendiği çift dilli yemek blogları çok modlu çeviriye bir örnektir. Bu durumda çevirmenin dilsel ve kültürel yetkinliğinin yanında, dijital okur yazarlığının gelişmiş olması da gerekmektedir. Bu çalışmada, öncelikle gastronomi metinleri kapsamında alt alan olarak değerlendirilen "yemek tarifleri" bir metin türü olarak çeviribilim odaklı bir bakış açısıyla ele alınmaya çalışılacak, ardından ise çeviri sürecinde karşılaşılabilecek olası sorunlar ve uygulanabilecek çeviri yöntemleri üzerinde durulacaktır.

\section{Bir metin türü olarak yemek tarifleri}

Genel anlamıyla yemek tarifi, bir yemeğin nasıl hazırlanacağını veya yapılacağını açıklayan bir dizi talimat içeren metindir. Tarifler, genellikle iki temel bölümden oluşur: (1) Malzemeler, (2) Yapılış adımları/Yöntem (pişirme tekniği, sunum tekniği vb.). Bunlara ek olarak yemek tarifleri, porsiyon sayısı, fırının sıcaklığı ve pişirme süresi gibi bilgiler de içerebilirler.

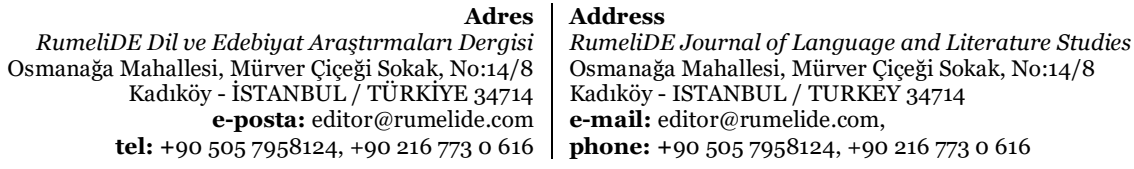


Katharina Reiss'ın metin tipolojisine göre, metinler temelde üç grupta toplanabilir. Bunlar, bilgilendirici (informative); yazınsal (expressive) ve işlemsel/işlevsel (vocative/operative) metinlerdir6 ${ }^{6}$. Bilgilendirici metinlerde içerik; yazınsal metinlerde biçim; işlemsel metinlerde ise ikna edicilik odak noktasını oluşturur. Buna bağlı olarak, bilgilendirici metinleri içeren çeviri sürecinde, çevirmen içerik odaklı düşünerek, anlamı dikkate alır; bilgi, fikir ve görüşleri hedef okura aktararak iletişimi etkin bir şekilde sağlamaya çalışır, gerektiğinde açımlama yoluna gidebilir. Yazınsal metin çevirilerinde, çevirmen biçimsel, biçemsel ve estetik kaygıları dikkate alır, anlatıma dayalı bir yöntem belirleyerek, kaynak metin yazarının bakış açısını erek metinde yansıtmaya çabalar. İşlemsel metin çevirilerinde ise, okurun harekete geçmesi ve hedef kitlede istenen tepkinin oluşması amaçlanır. Bu doğrultuda diyaloğa ve çağrı işlevine uygun bir dil kullanılır. Çeviride eşdeğer etkinin oluşmasını sağlamak amacıyla uyarlama yöntemi benimsenebilir (Reiss, 2000: 2443; akt. Munday, 2008: 73). Dolayısıyla, ders kitabı, akademik makale ve patent çevirileri bilgilendirici metin çevirisi; şiir, roman ve öykü çevirileri yazınsal metin çevirisi; reklam ve seçim konuşmaları çevirileri ise işlemsel metin çevirisi kapsamına girer.

Brinker (1997: 97-111), kullanmalık metinlerin (Gebrauchstext) beş ayrı işlevi olabileceğini belirtir. Bunlar,

(1) Bilgi aktarma işlevi: Haberler, ders kitapları ve raporlar gibi bilgilendirici içeriğe sahip olan metinlerin işlevidir.

(2) Çağrı işlevi: Reklamlar, propaganda konuşmaları gibi insanları etkilemeye ve inandırmaya yönelik metinlerin sahip olduğu işlevdir.

(3) Sorumluluk yükleyici işlev: Garanti belgesi, sözleșme, anlaşma gibi okurun bir yükümlülük üstlendiği metinlerin sahip olduğu işlevdir.

(4) İlişki işlevi: Tebrik etme ya da başsağlığı dileme gibi bireyler arasında iletişim kurma ve bu iletişimi sürdürmeye yönelik metinlerin sahip olduğu işlevdir.

(5) Bildirge işlevi: Vasiyetname ve vekaletname gibi resmi bir beyan içeren metinlerin sahip olduğu işlevdir (akt. Toklu, 2015: 189).

Öncelikle yemek tariflerinin kullanmalık metinler olarak kabul edilebileceğini söyleyebiliriz. Kullanmalık metinlerde dil, edebi metinlerde olduğunun aksine amaç değil, araçtır. Kullanmalık metinler, konusunu kendi varlığından yola çıkarak oluşturmaz; bu metinler dış gerçekliklerden yola çıkılarak oluşturulur. Bir soruna çözüm aramak üzere üretilmiş metinler olarak da kabul edilebilirler (Rolf, 1993; akt. Eruz, 1999: 47). Belli bir okur kitlesine ulaşmak bu metinlerin amacıdır ve kullanmalık metinler, Horst Belke'ye göre "insanları bilgilendirmeye, eğitmeye, öğretmeye, eğlendirmeye ve gerektiğinde ise eylemlerde bulunmaya çağırır" (akt. Özlük, 2017: 22). Kullanmalık metin olarak bir yemek tarifinin temel işlevleri, "bilgilendirme", "öğretme" ve "eyleme geçirme" olarak sıralanabilir. Bu yönüyle tarifler, karma (hybrid) yapıdadır. Reiss'ın metin tipolojisine göre, yemek tariflerinde içerik bir yandan bilgilendiricidir, çünkü metinlerde yemeğin hazırlanmasına ilişkin kullanılacak malzemeler ya da ihtiyaç duyulan ısı miktarı gibi birçok bilgi yer alır. Diğer yandan ise, tarifler okur ya da dinleyicileri yönlendiren talimatlar içerir. Bu talimatlara uyulursa yemeğin pişirilmesi ya da hazırlanması mümkün olur. Bu yönüyle de tarifler işlemsel metinler olarak kabul edilebilir. Brinker'ın sınıflandırmasına göre ise, yemek tarifleri bilgi aktarma ve çağrı işlevi olan metinlerdir.

Bu noktada, yemek tariflerinin yayımlandığı ortama (medium) ilişkin özelliklerden de söz etmek faydalı olacaktır. 21. yüzyılda teknolojik ilerlemeler kayda değer bir ivme kazanmış, yüz milyonlarca insan internet erişimine sahip olmuş ve böylece, bilgi dijital ortamlarda işlenmeye ve dolaşmaya başlamıştır. Bilgiye hızlı erişimle birlikte, dijital platformlar sayesinde sınırlar ortadan kalkmış ve içinde bulunduğumuz bilgi çağında basılı materyallerin yerini dijital metinler almıştır. Dijital metinlerin de kendi metinsel özellikleri

Terimlerin Türkçe karşılıkları için, bkz. Yazıcı, M. (2005: 143).

Adres | Address

RumeliDE Dil ve Edebiyat Araşturmalar Dergisi $\quad$ RumeliDE Journal of Language and Literature Studies

Osmanağa Mahallesi, Mürver Çiçeği Sokak, No:14/8 $\quad$ Osmanağa Mahallesi, Mürver Çiçeği Sokak, No:14/8

Kadıköy - ISTANBUL / TÜRKIYE 34714 Kadıköy - ISTANBUL / TURKEY 34714

e-posta: editor@rumelide.com e-mail: editor@rumelide.com,

tel: +90 505 7958124, +90 2167730616 phone: +90 505 7958124, +90 2167730616 
bulunmaktadır. Örneğin; geleneksel metinlerin aksine, dijital metinler durağan değil, etkileşimli ve dinamiktir. Bu metinler çok modlu (multimodal) bir yapıyla tasarlanır. Çok modluluk (multimodality) genellikle medya ve iletişim alanında kullanılan bir terim olup, iletişimin farklı șekilleri üzerine odaklanır. Çok modlu metinlerin temelde beş farklı moda sahip olabileceğini söyleyebiliriz: (1) Dilsel mod, yazılı ve sözlü dilsel malzemeyi içerir, tümce ve paragraf düzeyinde sözcük ve söz öbeklerinin konumlanması ve metnin organizasyonu, sözcük seçimleri, bağlam bilgisi, dilbilgisel yapı ve dilsel örüntüler gibi yazılı ve sözlü dile ilişkin konular da bu modun kapsamına girer (Arola vd., 2014: 5). (2) Görsel mod, metin içinde resim kullanımı, piktografik yazı, duyma engelliler için işaret dili kullanımı ve çizimler gibi unsurları içerir (Danesi, 2013: 476). Durağan ve hareketli görüntülerdeki renkler, vektörler ve perspektif de bu modun konuları arasında yer alır (Anstey ve Bull, 2010). Sayfa düzeni, italik/kalın karakterler ve yazı tipi boyutu da görsel modla ilgilidir. (3) İşitsel mod, seslerle ilgilidir. "müzik, ses efektleri, ortam gürültüsü/sesleri, sessizlik, konuşma dilindeki ses tonu, sesin şiddeti, vurgu ve aksan" (Arola vd., 2014: 8) bu mod kapsamına dahil edilir. (4) Hareket modu; yüz ifadeleri, el hareketleri, beden dili ve insanlar arasındaki etkileşim ile ilgilidir. Bazı durumlarda hareketlerin, mimiklerin, jestlerin ve beden dilinin doğru şekilde yorumlanması, anlama katkıda bulunabilir ve amaçlanan iletişimi kolaylaştırabilir (Arola vd., 2014: 12). (5) Uzamsal mod, daha çok konumlandırma ile ilgilidir. Bu mod, insanlar ve nesneler arasındaki fiziksel düzen, organizasyon ve yakınlığı ifade eder (Arola vd., 2014: 10).

Bir metnin çok modlu olabilmesi için yukarıdaki modlardan en az ikisini içermesi gerekir. Çok modlu metinlerde tüm modlar birbiriyle tutarlı olmalıdır, böylece ileti, erek okur ya da dinleyiciye amaçlandığı şekilde gönderilmiş olur. Çok modlu bir metinde yer alan tüm modlar eşit düzeyde vurgulanmayabilir, örneğin, dijital bir metinde görsel mod baskın iken, dilsel mod destekleyici konumda bulunabilir (Pekcoşkun Güner, 2021: 219). Bu açıklamaları göz önünde bulundurduğumuzda, günümüzde yemek tariflerinin dijital olarak tasarlandığını ve çok modlu bir özellik gösterdiğini söyleyebiliriz. Örneğin; üyelik sistemi ile çalışan ve üyelerine dijital platforma tarif metni (dilsel içerik), resim (görsel içerik) ve video (dilsel, görsel ve işitsel içerik) yükleme imkânı sunan uygulamalar mevcuttur. Bu uygulamalarda yer alan bir yemek tarifi incelendiğinde, farklı modlarla içerik oluşturulduğu ve böylece tarifin erek kitle için daha anlaşılır ve açık olmasının amaçlandığı söylenebilir. Yazılı olarak verilen tarif başlığı ve yönergeler dilsel moda; yapılıș sürecinde ve yemek tamamlandıktan sonra çekilerek ilgili platforma yüklenen fotoğraflar görsel moda; yemeğin yapılışını anlatan bir video varsa hareket moduna, işitsel moda ve uzamsal moda örnek olarak gösterilebilir.

Çeviri odaklı metin çözümlemesine yönelik olarak bir model geliştiren Christiane Nord, "metnin iletisini tamamlamak, örneklemek, yoğunlaştırmak veya belirsizliği gidermek" için kullanılan ve dilsel olmayan bileşenler olarak kabul edilebilecek olan "sözel olmayan unsurlardan" bahseder (2005: 118). Nord'a göre, bu unsurların sözel iletişimde tamamlayıcı bir rolü vardır, ayrıca bunlar jestler ve ses kalitesi gibi dil ötesi bileşenler, fotoğraflar, logolar ve illüstrasyonlar gibi yazılı bir metnin dilsel olmayan bileşenlerini içerirler. Çevirmen, kaynak metnin hangi sözel olmayan bileşenlerinin hedef metinde korunacağına ve hangilerinin hedef normlara göre uyarlanması gerektiğine karar vermelidir (2005: 121). Nord, işlevsel bir erek metin üretme sürecinde kaynak metnin sözel olmayan unsurlarının doğru yorumlanmasının öneminin altını çizmektedir. Burada, sözel olmayan unsurlar, çok modlu metinlerin dilsel olmayan modlarına karşıllık gelir. Çeviri sürecinde sözel olmayan unsurların nasıl ele alındığını ya da ele alınması gerektiğini anlamak oldukça önemlidir.

Günümüzde yemek tarifleri dijital ortamlarda ve çok modlu bir şekilde tasarlandığından, çevirmenin kullanılan tüm modlara ilişkin bir farkındalık geliştirmesi, modlar arasındaki ilişkileri çözümleyebilmesi ve modların birbirleriyle etkileşimini bütüncül bir bakış açısıyla yorumlayabilmesi daha işlevsel, erek odaklı

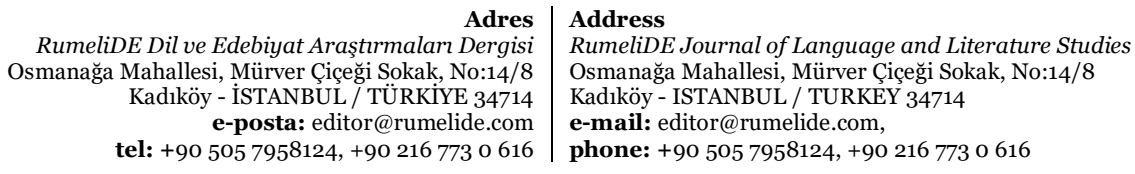


ve kabul edilebilir bir çevirinin ortaya çıkarılmasına katkı sağlayabilecektir. Çok modlu metin çevirisi, kaynak metin incelemesi sırasında her bir modun diğerlerinden soyutlanarak incelenmesini gerektirebilir. Ancak, modlar arasındaki etkileşimin metnin bağdaşıklığını oluşturduğu ve pekiştirdiği de unutulmamalıdır. Bu nedenle, çok modlu bir kaynak metnin incelenmesi, farklı modlar arasındaki ilişkilerin bilişsel olarak anlaşılmasını da kapsar. Bu yönüyle çok modlu çeviri, çeviri süreci açısından zorlayıcı olabilmektedir. Öte taraftan, farklı modların kullanımı çevirmenin kaynak metni anlamasını kolaylaştırabilir. Örneğin; çevirmen bir yemek tarifi çevirisi yapıyorsa, çeviri sürecinde yemeğin yapılış adımlarını kavrayarak, erek dile akıcı ve anlaşılır bir şekilde aktarmak için ilgili video ve görsellerden destek alabilir, işitsel ve görsel içerikleri iş istasyonuna dahil edebilir.

\section{Yemek tarifi çevirilerinin doğası}

Türk mutfağı dünyanın en ünlü ve çok çeşitliliğe sahip mutfaklarından biri olduğundan, özellikle kaynak dil olarak Türkçeden yapılan çevirilerde erek odaklı ve işlevsel bir yol izlemek önem taşımaktadır. Bu bölümde yemek tarifi çevirilerine ilişkin süreçte çevirmeni zorlayabilecek unsurlardan söz edilecektir. Bu unsurlar aynı zamanda kültüre özgü bileșenler olarak da kabul edilebilir.

Yemek tarifleri, kaynak kültüre özgü tatlar ve malzemeler içerdiğinden, kültürel unsurları da sıklıkla barındırır. Gıda çalışmaları ve çeviri etkinliğinin (süreç ve ürün) kesiştiği bir nokta vardır: kültürlerarası iletişim. Bir yüzyıl önce Kuzey Amerika'da çiğ balığın popüler bir lezzet olabileceği hayal dahi edilemezken, günümüzde suşi Amerika Birleşik Devletleri'nde en çok tercih edilen yemeklerden olmuştur (Desjardins v.d., 2015: 260). Türkiye için de durum farklı değildir. İstanbul gibi büyük kentlerde onlarca suşi restoranı bulunmaktadır. "Suşi tarifi" söz öbeğiyle, herhangi bir arama motoru kullanılarak gerçekleștirilen bir sorgudan ise binlerce sonuç alınmaktadır. Kültürlerarası etkileşim ve dijital platformlar aracılığıyla farklı mutfak kültürlerine ilişkin bilgiler günümüzde kolaylıkla edinilebilmektedir. Böylece, değişik coğrafyalara ait malzemeler ile farklı mutfaklara ait yemek ve tarifler dünya çapında dolaşıma girmiştir ve bireyler yerel mutfaklarına özgü tatlar yanında, değişik yöre ve kültürlere ait yemekleri de denemek istemektedir. Newmark, çeviri ve kültür ilişsisini ele alırken, yemeği "materyal kültür” ürünleri içinde konumlandırmıştır. Yemek, birçokları için ulusal kültürün en hassas ve önemli ifadesidir; mutfak terimleri çok çeşitli çeviri prosedürlerine tabidir. Örneğin; menüler, yemek kitapları ve yemek kılavuzları, turist broşürleri, gazete metinleri yabancı mutfaklara ait terimler içermektedir (1988: 97).

Yemek tarifleri gündelik metinler gibi görünse de alana özgü dil ve terminoloji içeren metinlerdir. Terim çevirileri yapılırken tek dilli, çift dilli ve çok dilli terimceler ile terim veritabanları çevirmenlere yardımcı olabilir. Tablo 1'deki örnekte genel anlamı dışında, bir gastronomi terimi olarak kullanılan "küvet" sözcügü görülmektedir.

\begin{tabular}{|l|l|}
\hline Türkçe (Kaynak dil) & İngilizce (Erek dil) \\
\hline $\begin{array}{l}\text { Zeytinyağı ile yağlanmış derince bir küvete hamuru koyup } \\
\text { hamurun hacminin 2/3'si kadar daha kabarmasını bekleyin.7 }\end{array}$ & $\begin{array}{l}\text { Place this dough in a deep basin oiled with olive } \\
\text { oil, letting it rise up to } 2 / 3 \text { of its volume. }\end{array}$ \\
\hline
\end{tabular}

Tablo 1. Yemek tariflerinde terim kullanımı

Gastronorm küvetler, genellikle endüstriyel mutfak malzemeleri olarak kabul edilir. Geniş, yayvan ve paslanmaz çelikten üretilen bu kaplar, endüstriyel fırınlarda yemek pişirmek için kullanılır. Çift dilli bir

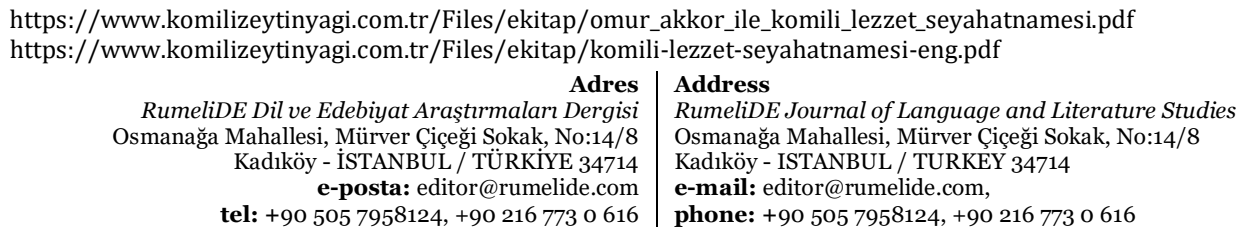


sözlükte kaynak ifadenin erek dildeki karşlığı arandığında çıkan ilk sonuç “tub” olmaktadır. Makine çevirisi sistemleri de aynı sonucu vermektedir. Ancak "tub" bir mutfak terimi değildir. Tablo 1'de verilen örnekte, "küvet" sözcüğü gündelik anlamı dışında kullanılıp terim özelliği kazanmıştır.

Teknik metin çevirilerinde olduğu gibi, gastronomi metinleri çevirisi de sayısız tuzaklarla doludur. Bu tür metinlerin çeviri sürecinde karşılaşılan tuzaklardan biri yalancı eşdeğerler (false friends) olup, sıklıkla karıştırılan sözcük ve ifadelerin varlığı da bir diğer sorundur (Paradowski, 2010: 139-140). Tablo 2'de9 Türkçe "İç baklalı - kırmızılahanalı fenerbalığı salatası" başlıklı yemek tarifinden iki bölüm yer almaktadır.

\begin{tabular}{|c|c|}
\hline Malzemeler & Hazırlanışı \\
\hline$\cdots$ & \\
\hline 2 çorba kaşı̆̆ı sirke & Sosu hazırlamak için nane, balık (ya da tavuk) suyu, sirke ve çiçekyağını bir kâsede \\
\hline $\begin{array}{l}1 \text { çorba kaşığı } \\
\text { çiçekyağ }\end{array}$ & $\begin{array}{l}\text { karıştırın. Bu sosu balık ve sebzelerin üstlerine döküp, iyice karıştırdıktan sonra, kabı buz } \\
\text { dolabına kaldırıp, salatayı } 30 \text { dakika soğutun. }\end{array}$ \\
\hline $\begin{array}{l}1 \text { çorba kaşı̆̆ } \\
\text { maydanoz (kıyılmış) }\end{array}$ & $\begin{array}{l}\text { Kabı buzdolabından alıp, maydanozu salataya ekleyerek, hafifçe karıștırın. Yeşil salata } \\
\text { yapraklarını } 4 \text { düz tabağa yerleştirip, salatayı bir kaşıkla yaprakların üstüne }\end{array}$ \\
\hline $\begin{array}{l}1 \text { yeşil salata } \\
\text { (yıkanıp, } \\
\text { kurulanmış) }\end{array}$ & bölüştürdükten sonra, servis yapın. \\
\hline
\end{tabular}

Tablo 2. Yemek tarifi örneği

"Salata” TDK Güncel Sözlükte, "genellikle bazı çiğ ot ve sebzelerle yapılan, yağ, limon vb. maddeler konulan, yemeklerle birlikte yenen yiyecek" olarak tanımlanmıștır ${ }^{10}$. Tablo 2'deki örnekte, malzemeler bölümünde "1 yeșil salata" ifadesi bulunmaktadır. Parantez içinde yer alan, "yıkanıp, kurulanmış" ifadesi ise günümüz "salata" kavramı ile pek bağdaşmamaktadır. Hazırlanış adımlarına baktığımızda ise, iki farklı "salata"dan söz edildiği anlaşılmaktadır. Birinci salata, yemeğin kendisi, yani "iç baklalı - kırmızı lahanalı fenerbalı̆̆ı salatası"dır. Maydanoz da bu salataya eklenerek tüm malzemeler karıştırılır. İkinci salata ise, malzemeler bölümünde "1 yeşil salata" olarak; hazırlanışı bölümünde ise "yeşil salata" olarak adı geçen "salata"dır. Metni ilk kez okuduğunda, okur metinde bir kavram kargaşası olduğunu düşünebilir. Yemeğin görselinde ise, yuvarlak bir tabakta, balıklı salata marul yaprakları üzerinde durmaktadır. Dolayısıyla, "1 yeşil salata" ile kastedilen "1 top/adet marul" dur. Yemek kitabının giriş bölümünde de "Çeşit çeşit salata yaprağı" başlıklı bir bölüm bulunmakta ve bu bölümde roka, pancar yaprağı, karahindiba, kuzukulağı, Çin lahanası, suteresi gibi sebze ve otlar tanıtılmaktadır. Malzemeler kısmında yer alan "yeşil salata"nın doğrudan "green salad" olarak erek dile aktarılması anlam karışıklığına neden olarak, yalancı eşdeğer tehlikesini beraberinde getirebilir. Erek dilde yemek tarifleri incelendiğinde "green salad" ifadesinin, genellikle yeşil sebzelerden oluşan salatalar için kullanılan bir üst terim olduğu görülmektedir. Yeşil sebzelerin mutlaka yer aldığı yeşil salatalara, "yeşil olmayan" (domates, ceviz içi vb.) sebze ve çerezler de eklenebilir. Bu durumda, anlam karmaşasını ortadan kaldırmak ve erek metinde tutarlığı sağlamak amacıyla, çevirmenin "1 yeşil salata (yıkanmış, kurulanmış)" ifadesini "marul" (en. lettuce) olarak erek dile aktarması, "yeşil salata yaprakları" ifadesini ise "marul yaprakları" (en. lettuce leaves) olarak çevirmesi gerekecektir. Dolayısıyla, kaynak metinde yer alan tüm "salata" ifadelerini, "salad" olarak erek dile aktarmak metnin anlam bütünlügünü zedeleyecektir.

Paradowski, gastronomi metinlerinin alana özgü bir dile sahip olduğunu vurgular ve buradaki alana özgü dil "mutfak altdili" (culinary lingo) olarak kabul edilir (2010: 139). Hazırlama teknikleri, sadece sözcük

(t.y). Mutfak Ansiklopedisi: Salatalar, Yahniler ve Hamur İşleri, (2. Cilt). İstanbul: Sabah Dış Ticaret ve Pazarlama A.Ş. https://sozluk.gov.tr/

RumeliDE Dil ve Edebiyat Araştırmaları Dergisi Osmanağa Mahallesi, Mürver Çiçeği Sokak, No:14/8 Kadıköy - İSTANBUL / TÜRKIYE 34714 e-posta: editor@rumelide.com tel: +90 $5057958124,+902167730616$

Address

RumeliDE Journal of Language and Literature Studies Osmanağa Mahallesi, Mürver Çiçeği Sokak, No:14/8

Kadıköy - ISTANBUL / TURKEY 34714

e-mail: editor@rumelide.com,

phone: +90 505 7958124, +90 2167730616 
bilgisi değil, aynı zamanda teknik bilgi de gerektiren başka bir mayın tarlasıdır. Genel bir anlama sahip olan "pişirmek" fiili o kadar geniş anlamlı bir terimdir ki, "kaynatmak"tan çok daha fazlasını kapsar, çoğu zaman uygun çeviri eşdeğerini bulmak, tarifin dikkatli bir şekilde incelenmesini gerektirir. Anlamların bağlamsal olarak daraltılması, fiil seçiminde kilit bir rol oynar (Paradowski, 2010: 142). Örneğin; malzemeler karıştırılırken bir alet kullanımı söz konusu ise duruma göre, "karıştırmak" yerine, "çırpmak" fiili tercih edilebilir.

Terminoloji kaynaklı sorunlara örnek olarak etin bölümlerine ilişkin çeviriler verilebilir. Farklı kültürlerde etin bölümlerinin farklı kavramlara karşılık geldiğini söylemek yanlış olmaz. Terim çevirisi gerçekleştirilmiş olsa bile, kullanılan erek terim, kaynak ve erek dilde aynı vücut parçasına karşlık gelmeyebilir. Böyle bir durumda bir uzmandan yardım almak ya da etin bölümlerine ilişkin resim ve çizelgeleri incelemek yararlı olabilir (Epstein, 2009; Köhler, 2011). Örneğin; dananın üst sırt kısmından elde edilen et, Türkiye'de genellikle "antrikot" olarak adlandırılır. Kuzey Amerika'da ise aynı vücut bölgesi için iki farklı terim kullanılır. Hayvanın boyun bölgesine yakın olan ya da boynu ile kürek kemiği arasında kalan kısım için "chuck"; kaburga kısmından alınan ete ise "rib" adı verilmektedir.

Kültüre özgü terimlerin çevirisinde farklı yöntemler kullanılabilir. Örneğin; Türk mutfak kültüründe "kulak memesi kıvamı" gastronomi alanında sıklıkla kullanılan bir terimdir. Bu kıvam, hamurun ele yapışmayacak hale geldiği noktadır.

\begin{tabular}{|l|l|}
\hline Türkçe (Kaynak dil) & İngilizce (Erek dil) \\
\hline $\begin{array}{l}\text { Un, tuz ve yeterince su ile kulak memesi yumuşaklığında bir hamur } \\
\text { yoğurup onu iki bezeye ayırın. }{ }^{11}\end{array}$ & $\begin{array}{l}\text { Prepare the dough with flour, salt and water; } \\
\text { separate it into two. }{ }^{12}\end{array}$ \\
\hline Bir tencerede soğan ve sarımsak zeytinyağında öldürülür. & $\begin{array}{l}\text { Saute the onions and garlic in a frying pan } \\
\text { until golden brown. }{ }^{13}\end{array}$ \\
\hline
\end{tabular}

Tablo 3. Kültüre özgü terimlerin çevirisi

Tablo 3'teki ilk örnekte çevirmen "kulak memesi yumuşaklığında" ifadesine erek metinde yer vermemiş, başka bir deyişle ifadeyi çıkarma yoluna gitmiştir. İkinci örnekte ise, "öldürmek" ifadesi, "saute ... until golden brown" (pembeleşinceye kadar soteleyin) șeklinde erek kültüre tanıdık gelebilecek bir ifadeyle çevrilmiştir. Dolayısıyla erek odaklı bir bakış açısıınn benimsendiği söylenebilir. Kültüre özgü mutfak terimlerine örnek olarak, tutam, çimdik, fiske; aldığı kadar un, kokusu çıkana kadar, terbiyelemek, göz kararı, suyunu çekene kadar, boca etmek verilebilir (Coşkun, 2021). Çevirmenler, kültüre özgü terimlerin çevirisinde, çevirinin amacı ve çeviri yönergesine paralel şekilde, farklı yaklaşımlar uygulayabilirler.

Yemek tarifi çevirilerinde dikkat edilmesi gereken bir unsur da ölçü birimlerinin çevirisidir. Aşçllık eğitimi genellikle bölgeye özgüdür. Avrupa'da eğitim almış olan şefler, çoğunlukla metrik sistem kullanırken, Birleşik Krallık ve Kuzey Amerikalı şefler, imparatorluk ölçü birimlerini kullanırlar. Amaç erek odaklı bir çeviri gerçekleştirmek ise, birimlerin doğru bir şekilde dönüştürülmesi oldukça önem taşır. Tablo 4'te verilen örnekte görüldüğü gibi, kaynak dilde yer alan "Celcius" ifadesi erek dile "Fahrenheit" olarak aktarılmıştır.

Türkçe (Kaynak dil)

İngilizce (Erek dil)

https://www.anadolujet.com/tr/kurumsal/anadolujet-magazin/2016/3/kis-biterken

https://www.anadolujet.com/en/corporate/anadolujet-magazine/2016/3/as-winter-ends

http://skylibrary.net/issues/com.turkishairlines.ajet/webreaderHTML/complete/index.html\#/spread/42

Adres | Address

RumeliDE Dil ve Edebiyat Araştırmaları Dergisi Osmanağa Mahallesi, Mürver Çiçeği Sokak, No:14/8 Kadıköy - İSTANBUL / TÜRKIYE 34714 e-posta: editor@rumelide.com

RumeliDE Journal of Language and Literature Studies Osmanağa Mahallesi, Mürver Çiçeği Sokak, No:14/8

Kadıköy - ISTANBUL / TURKEY 34714 tel: +90 $5057958124,+902167730616$

e-mail: editor@rumelide.com,

phone: +90 505 7958124, +90 2167730616 
Önceden $170^{\circ} \mathrm{C}^{\prime}$ de Isıtılmıs firında yaklaşılk 40 dakika pişirin. ${ }^{14}$
Then bake it in the preheated oven at $338^{\circ} \mathrm{F}$ for 40 minutes. ${ }^{15}$

Tablo 4. Ölçü birimlerinin uyarlanması

Dönüştürme çizelgeleri, çevirmenin ölçüleri erek kültürün sistemine aktarmasına yardımcı olsa da, kültüre özgü bu öğelerin çevirisinde yine de hatalar meydana gelebilir. Çevirmenler onsu (ounce) doğrudan grama dönüştürebilir ve sonuçta gerçekçi olmayan miktarlar ortaya çıkabilir. Örneğin; imparatorluk ölçü sisteminde 5 ons, metrik sistemde 141.7 grama eşittir. Bu durumda okurun yemek pişirmek için hassas teraziye ihtiyacı olacaktır. Çevirmen, 5 ons bezelyeyi yuvarlayarak 150 grama çevirebilir, çünkü 8.3 gram bezelye bir çay kaşığından fazla değildir. Bezelye çorbası hazırlarken bu küçük miktar sonucu değiştirmeyecektir. Genellikle, bu küsuratlı miktarlar, sonucu değiştirmeden yukarı veya aşağı yuvarlanabilir (Kerseboom, 2010: 35). Ölçü birimlerinin doğru bir şekilde erek kültür ölçü sistemine uyarlanması ve gerektiğinde miktarın yuvarlanarak erek dile aktarılması işlevsel bir çeviri ile sonuçlanabilecektir.

Kaynak ve erek dilin metin geleneklerinin, anlamsal, sözdizimsel, biçimsel ve dilbilgisel özelliklerinin çevirmen tarafından bilinmesi çeviri sürecini daha verimli kılabilir. Özellikle işlevsel, kabul edilebilir ve dolayısıyla erek odaklı bir çeviri amaçlanıyorsa, kaynak metne özgü dilsel yapıları erek dilde yaygın olarak tercih edilen yapılara dönüştürmek gerekebilir. Böylece okur, erek metni kendi dilinde yazılmış özgün bir metinmiş gibi algılar. Özgün Türkçe ve İngilizce yemek tarifleri incelendiğinde, en önemli farklılık fiillerin kullanım biçimlerinde ortaya çıkmaktadır. İngilizce özgün yemek tarifleri analiz edildiğinde, fiillerin çoğunlukla yalın eylemlik (bare infinitive) yapısında emir kipiyle kullanıldığı görülmüștür.

Dominika Klenová, İngilizce yemek kitapları ve yemek tariflerinin dilini incelediği çalışmasında, ünlü İngiliz șefler, Nigella Lawson, Jamie Oliver ve Gordon Ramsay'in yemek kitaplarını incelemiş, fiillerin ezici bir çoğunlukla yalın eylemlik yapıda ve emir kipiyle kullanıldığı sonucuna varmıştır (2010: 67-68).

\begin{tabular}{|l|l|}
\hline Türkçe (Kaynak dil) & Ingilizce (Erek dil) \\
\hline $\begin{array}{l}\text { 1. Patlıcanları alacalı soyun ve iki parmak kalınlığında kesin } \\
\text { (Emir kipi). }\end{array}$ & $\begin{array}{l}\text { Peel the eggplants in alternating strips and chop into } \\
\text { strips two fingers thick (Emir kipi). }{ }^{16}\end{array}$ \\
\hline $\begin{array}{l}\text { 2. Yağ derin bir tavada kızdırılıp önce pırasalar arkalı önlü } \\
\text { kızartılarak tencereye sıralanır (Edilgen yapı). }\end{array}$ & $\begin{array}{l}\text { Heat oil in a deep pan, fry the leeks, and line them up } \\
\text { in a pot. (Emir kipi). }{ }^{17}\end{array}$ \\
\hline $\begin{array}{l}\text { 3. Kabuklarını ayıkladıktan sonra küçük küçük doğrayıp bir } \\
\text { tencereye koyalım (Dilek kipi). }\end{array}$ & $\begin{array}{l}\text { After peeling off the burnt outer layer, dice them and } \\
\text { place in a saucepan (Emir kipi). }{ }^{18}\end{array}$ \\
\hline
\end{tabular}

Tablo 5. Kaynak ve erek dilde dilbilgisi unsurları

Tablo 5'te görüldüğü gibi, Türkçe özgün yemek tariflerinde, fiiller emir kipinde (1. tümce, "kesmek" fiili); edilgen yapıda (2. tümce, "sıralamak" fiili) ya da dilek kipinde (3. tümce, "koymak" fiili) kullanılabilir. Ancak bu tabloda dikkat çeken unsur, çevirmenin farklı fill yapıları ile oluşturulmuş Türkçe kaynak tümcelerin

\footnotetext{
14 https://www.anadolujet.com/tr/kurumsal/anadolujet-magazin/2016/5/ege-ve-akdenizin-ozel-lezzetleri

15 https://www.anadolujet.com/en/corporate/ anadolujet-magazine/2016/5/exceptional-flavors-from-the-aegean-andmediterranean

http://skylibrary.net/

issues/com.turkishairlines.ajet/83ECE1F22755B9D5E2A6FA4840B5241A/webreaderHTML/complete/index.html\#/sprea $\mathrm{d} / 66$

17 http://skylibrary.net/ issues/com.turkishairlines.ajet/F610DB5AAE4362AFB89FAB7D943C4373/webreaderHTML/ complete/index.html\#/spread/48

http://skylibrary.net/issues/

com.turkishairlines.ajet/7C1751FF520CDC51E8EED93FCED7D224/webreaderHTML/complete/index.html\#/spread/42

Adres $\mid$ Address

RumeliDE Dil ve Edebiyat Araştırmalar Dergisi Osmanağa Mahallesi, Mürver Çiçeği Sokak, No:14/8 Kadıköy - ISTANBUL / TÜRKIYE 34714 e-posta: editor@rumelide.com

RumeliDE Journal of Language and Literature Studies Osmanağa Mahallesi, Mürver Çiçeği Sokak, No:14/8

Kadıköy - ISTANBUL / TURKEY 34714

e-mail: editor@rumelide.com tel: +90 $5057958124,+902167730616$ phone: +90 505 7958124, +90 2167730616
} 
tümünü erek dile yalın eylemlik yapıda ve emir kipiyle aktarmasıdır. Dolayısıyla, çevirmenin erek metin geleneklerini dikkate aldığını, erek odaklı bir çeviri gerçekleştirmek amacıyla kaynak metinde yer alan dilbilgisi yapılarını değiştirdiğini söylememiz mümkündür.

\section{Yemek tarifi çevirilerinde temel yöntemler}

Yemek tarifi metinlerinde yer alan kültürel unsurların çevirisinde farklı yöntemler uygulanabilmektedir. Aixelà, kültüre özgü unsurların çevirisine yönelik stratejileri iki temel grupta toplamıştır: Koruma (conservation) ve değiştirme (substitution). Tekrar (repetition), ortografik uyarlama (ortographical adaptation), dilsel (kültürel olmayan) çeviri (linguistic/non-cultural translation), metin-dışı açıklama (extratextual gloss) ve metin-içi açıklama (intratextual gloss) koruma stratejileri olarak ele alınır (1996: 6062). Bu stratejiler, kaynak kutba daha yakın bir erek metin üretimi sağlarken, koruma stratejilerinin Venuti'nin öne sürdüğü yabancılaștırma yöntemi ve Schleiermacher'in "okuru yazara götüren" yaklaşımı ile benzer olduğu söylenebilir (Venuti, 1998: 242; Schleiermacher, 2004: 49; akt. Munday, 2008: 145).

İkinci temel grup olan değiştirme stratejileri ise beş başlıkta incelenebilir. Bunlar; eş anlamlılık (synonymy), sinırl evrenselleștirme (limited universalization), mutlak evrenselleştirme (absolute universalization), yerlileştirme (naturalization), çıkarma (deletion) ve öz-yaratım (autonomous creation) olarak sıralanabilir. Değiştirme stratejileri, Venuti'nin yerlileștirme stratejisi ve Schleiermacher'in öne sürdüğü "yazarı okura götüren" yaklaşım ile benzerdir (Venuti, 1998: 241; Schleiermacher, 2004: 49; akt. Munday, 2008: 144).

Aynı zamanda Vinay ve Darbelnet'nin doğrudan çeviri yöntemleri (ödünçleme, öyküntü ve sözcüğü sözcüğüne çeviri) Aixelà tarafından önerilen koruma stratejileri ile özdeşken, erek kutba daha yakın bir çeviriyi öngören dolaylı çeviri yöntemleri (aktarım, modülasyon, eşdeğerlik, uyarlama) değiştirme stratejileri ile benzer özellikler gösterir (Vinay ve Darbelnet, 1995: 31-41).

\subsection{Dipnot kullanımı}

Çeviride dipnot kullanımı, Aixelà'ya göre "metin-dışı açıklama" kategorisine dahildir ve kültüre özgü unsurların açıklanması gerektiği düşünüldüğünde bu yöntem kullanılabilir. Ancak, açılama metin içinde yer almaz (1996: 62).

Genel olarak gastronomi metinleri çevirileri düşünüldüğünde, kültüre özgü bazı ifadelerin dipnot verilerek açıklandığı görülmektedir. Kaynak kültüre ait yiyecekler erek dile aktarılırken metin-dışı açıklamalarda bulunulabilir.

\begin{tabular}{|l|l|}
\hline Türkçe (Kaynak dil)19 & İngilizce (Erek dil)º \\
\hline $\begin{array}{l}1 \text { yemek kaşığı labne } \\
\text { peynir }\end{array}$ & $\begin{array}{l}1 \text { table spoon labne* cheese } \\
\text { * "Labne” is a soft, thick and creamy cheese, similar in texture to cream cheese, made } \\
\text { from strained yoghurt. }\end{array}$ \\
\hline
\end{tabular}

Tablo 6. Kültüre özgü unsurlara ilişkin dipnot kullanımı

Tablo 6'da verilen örnekte Ortadoğu kültürüne ait bir peynir çeșidi olan "labne", dipnot verilerek ayrıntılı bir şekilde tanımlanmıştır. Labne, sürülebilir bir peynir çeşididir ve farklı ülkelerde labni, labneh, lebneh ve labaneh gibi isimler alır. Labne sözcügü, Arapçada süt anlamına gelen laban kelimesinden türemiştir²1. Erek

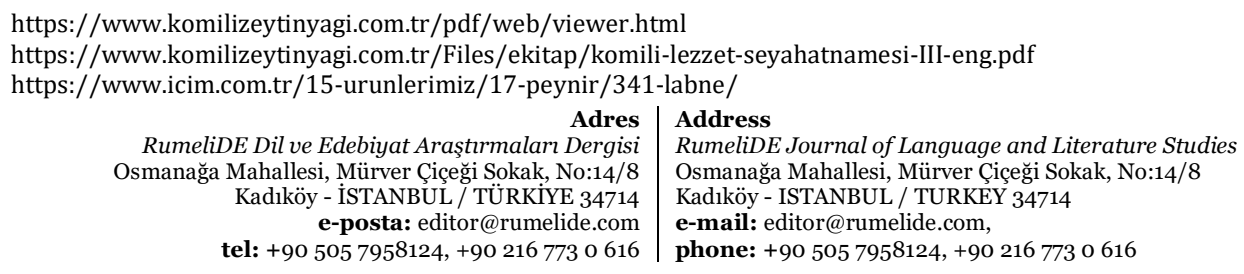


kültüre "yabancı" gelebilecek bir sözcük olan "labne" dipnotta italik şekilde yazılmıştır. Böylece çevirmenin metin içinde görünür olduğu, bir yandan kaynak metinde yer alan kültüre özgü ifadeyi korurken, diğer yandan dipnot vererek erek okurun söz konusu kavramı zihninde canlandırabilmesini sağlamaya çalıştığı yorumu yapılabilir. Dipnotlar kaynak mutfak kültürünün erek kültüre tanitılmasında da önemli rol oynamaktadır.

\subsection{Açımlama}

Açımlama (explicitation), kaynak dilde örtük olan ifadeleri erek dilde açlk hale getirmek anlamına gelen biçemsel bir çeviri tekniği olarak tanımlanır ve bağlamdan ya da durumdan yola çıkılarak açımlamalarda bulunulabilir. Ancak, çok fazla uygulanması, "aşırı çeviriye" yol açar (Vinay ve Darbelnet, 1995: 342). Vinay ve Darbelnet'ye göre, açımlama yönteminin başarısı çevirmenin eğitimine, bilgi birikimine, bakış açısına bağlı olarak değişebilir (1995: 185). Açımlama yöntemi, Aixelà'nın önerdiği metin içi açıklama yöntemiyle benzerdir. Tablo 7'deki örnekte, açımlama yönteminin uygulanışı görülmektedir.

\begin{tabular}{|l|l|}
\hline Türkçe (Kaynak dil) & İngilizce (Erek dil) \\
\hline $\begin{array}{l}\text { Not: Halen Isparta ve yöresinde yaz ayları çemen } \\
\text { sürülen az etli kaburgalar güneşte iyice }\end{array}$ & $\begin{array}{l}\text { Note: In Isparta and its area, ribs with little meat are rubbed } \\
\text { kuruth "çemen"-a pungent mixture of spices-in the summer. } \\
\text { asılır. }\end{array}$ \\
$\begin{array}{l}\text { After being dried in the sun, they are put in cloth bags and } \\
\text { hung up in cellars. }{ }^{22}\end{array}$ \\
\hline
\end{tabular}

Tablo 7. Türkçe-İngilizce dil çiftinde bir çeviri yöntemi olarak açımlama

“Çemen" Türk mutfak kültürüne özgü bir malzeme olduğundan ve erek kültür tarafından bilinemeyebileceği düşünüldüğünden, çevirmenin açımlama yöntemini kullanarak, erek okurun söz konusu kavramı zihninde canlandırmasını sağlamaya çalıştığını söyleyebiliriz.

Tariflerde, Türk mutfağına ait yemeklere ilişkin kısa ve genel açıklamalara da erek metinde yer verildiğini görmek mümkündür. Tablo 8'de kaynak dilde "hazırlanıșı" olarak yer alan bölümün karşısında "directions" şeklindeki çeviriye ek olarak yemeğe ilişkin bir açıklama da getirilmiştir. Bu açıklama kaynak metinde bulunmamaktadır.

\begin{tabular}{|l|l|}
\hline $\begin{array}{l}\text { Türkçe (Kaynak } \\
\text { dil) }\end{array}$ & İngilizce (Erek dil) \\
\hline Hazırlanışı: $^{23}$ & $\begin{array}{l}\text { Directions: } \\
\text { Balıklen is a meat dish made from liver, but its fishy taste is the source of its name ("balık" } \\
\text { means fish in Turkish.) } 24\end{array}$ \\
\hline
\end{tabular}

Tablo 8. Erek metne açıklama eklenmesi

Tablo 9'da verilen yemek adları çevirilerinde de açımlama yöntemine başvurulduğu görülmektedir:

\begin{tabular}{|l|l|}
\hline Türkçe (Kaynak dil) & İngilizce (Erek dil) \\
\hline
\end{tabular}

\footnotetext{
22 http://skylibrary.net/issues/

com.turkishairlines.ajet/7663BE46E00FE8276B50814280070BC7/webreaderHTML/complete/index.html\#/spread/56 https://www.anadolujet.com/tr/kurumsal/anadolujet-magazin/2016/5/ege-ve-akdenizin-ozel-lezzetleri

https://www.anadolujet.com/en/corporate/ anadolujet-magazine/2016/5/exceptional-flavors-from-the-aegean-andmediterranean

Adres
RumeliDE Dil ve Edebiyat Araştırmaları Dergisi Osmanağa Mahallesi, Mürver Çiçeği Sokak, No:14/8 Kadıköy - ÍSTANBUL / TÜRKIYE 34714 e-posta: editor@rumelide.com tel: +90 505 7958124, +90 2167730616

Address

RumeliDE Journal of Language and Literature Studies Osmanağa Mahallesi, Mürver Çiçeği Sokak, No:14/8

Kadıköy - ISTANBUL / TURKEY 34714

e-mail: editor@rumelide.com,

phone: +90 5057958124 , +90 2167730616
} 


\begin{tabular}{|l|l|}
\hline Hardaliye & $\begin{array}{l}\text { Mustard-seed Grape Juice } 25 \\
\text { (Hardal Tohumlu Üzüm Suyu) }\end{array}$ \\
\hline Çömlek Eti & $\begin{array}{l}\text { Anatolian Tandoor Style Meat }{ }^{26} \\
\text { (Anadolu Usulü Tandır Eti) }\end{array}$ \\
\hline
\end{tabular}

Tablo 9. Yemek adları çevirisinde açımlama yöntemi

\subsection{Sözcüğü sözcüğüne çeviri}

Sözcüğü sözcüğüne çeviri, bir kaynak metin unsurunun, erek dilin dilbilgisel yapısına ve ifade biçimlerine uygun olarak doğrudan aktarımıdır. Bu yöntemi uygulayan çevirmen, erek dilin dilsel özelliklerine bağlı kalır (Vinay ve Darbelnet, 1995: 34). Tablo 10'da sözcüğü sözcüğüne çeviri yönteminin uygulanışı görülmektedir.

\begin{tabular}{|l|l|}
\hline Türkçe (Kaynak dil) & İngilizce (Erek dil) \\
\hline Şalgam Püresi ${ }^{27}$ & Turnip Puree ${ }^{28}$ \\
\hline Çiğ Mantar Salatası $^{29}$ & Raw Mushroom Salad30 \\
\hline
\end{tabular}

Tablo 10. Sözcüğü sözcüğüne çeviri

\subsection{Yabancılaștırma}

Yabancılaştırma (foreignization), erek dilde baskın olan kültürel unsurları dışlayarak gerçekleştirilen bir çeviri yöntemidir. Bu yöntem, Schleiermacher'in "okuru yazara götüren" yaklaşımıyla benzeşmektedir (Venuti, 1998: 242; Schleiermacher, 2004: 49; akt. Munday, 2008: 145). Yabancllaştırma yöntemi ile erek metinde çevirmen daha "görünür" kılınır ve okur, okuma süreci boyunca yabancı bir kültüre ait olan metni okuduğunun farkındadır (Venuti, 1995). Yabancılaștırma yönteminde kaynak metin yapısına bağlı kalınabilir, kaynak metnin "yabancı" kimliği ön plana çıkarılır, okur "çeviri" bir metin okuduğunu bilir ve böylece metin erek kültürün ideolojik baskısından korunmuş olur.

\begin{tabular}{|l|l|}
\hline Türkçe (Kaynak dil) & İngilizce (Erek dil) \\
\hline Ulubey Döndürmesi³1 & Ulubey Döndürmesi ${ }^{2}$ \\
\hline Analı Kızlı & Analı Kızlı (Mother and daughter) ${ }^{33}$ \\
\hline
\end{tabular}

Tablo 11. Yabancılaştırma yöntemi

Tablo 11'de verilen örneklerde, yabancılaştırma yönteminin tercih edildiği söylenebilir. Böylece, çevirmenin erek metne yerel bir renk katmak istediği düşünülebilir. Bazen bu yönteme, son örnekte görüldüğü gibi sözcüğü sözcüğüne çeviri de eşlik eder. Çevirmen, Türkçe karakterleri (ö, ü, l) de olduğu gibi bırakmış, erek dil İngilizcenin ortografik yapısına uydurmamıştır.

\footnotetext{
25 http://skylibrary.net/issues/ com.turkishairlines.ajet/ B5165DF1F9E4E0C1640CC38A5B9E9655/webreaderHTML / complete/index.html\#/spread/66

https://www.anadolujet.com/tr/kurumsal/anadolujet-magazin/2016/4/gozden-uzak-lezzetler

https://www.anadolujet.com/tr/kurumsal/anadolujet-magazin/2014/3/leziz-ve-saglikli-salgam

https://www.anadolujet.com/en/corporate/anadolujet-magazine/2014/3/delicious-and-healthy-turnip

https://www.anadolujet.com/tr/kurumsal/anadolujet-magazin/2014/9/protein-deposu-mantar

https://www.anadolujet.com/en/corporate/anadolujet-magazine/ 2014/9/a-rich-protein-source- mushrooms

https://www.anadolujet.com/tr/kurumsal/anadolujet-magazin/2016/4/gozden-uzak-lezzetler

https://www.anadolujet.com/en/corporate/anadolujet-magazine/2016/4/concealed-tastes

http://skylibrary.net/issues/com.turkishairlines.ajet/20170401-upload/201103/webtablet/index.html\#/spreads/39

Adres $\mid$ Address

RumeliDE Dil ve Edebiyat Araşturmaları Dergisi Osmanağa Mahallesi, Mürver Çiçeği Sokak, No:14/8 Kadıköy - İSTANBUL / TÜRKIYE 34714 e-posta: editor@rumelide.com

RumeliDE Journal of Language and Literature Studies

Osmanağa Mahallesi, Mürver Çiçeği Sokak, No:14/8

Kadıköy - ISTANBUL / TURKEY 34714

e-mail: editor@rumelide.com,

tel: +90 505 7958124, +90 2167730616 phone: +90 505 7958124, +90 2167730616
} 


\subsection{Yerlileștirme}

Yerlileștirme (domestication), etno-merkezci bir yaklaşımla, erek metnin erek dilin kültürel unsurlarına uygun şekilde dönüştürülmesi olarak tanımlanabilir. Schleiermacher'in "yazarı okura götüren" yaklaşımıyla benzer olan bu yöntemde, erek metin okura yabancı gelebilecek unsurlardan arındırılır (Venuti, 1998: 241; Schleiermacher, 2004: 49; akt. Munday, 2008: 144). Okur, kendi dilinde yazılmış bir metin okuduğu hissine kapılır ve çeviri erek okur tarafından, "akıcı" olarak nitelendirilir. Yabancllaştırma yönteminin tersine, yerlileştirme yöntemini benimseyen bir çevirmen erek metinde görünmez olur.

\begin{tabular}{|l|l|}
\hline Türkçe (Kaynak dil) & İngilizce (Erek dil) \\
\hline Çayın yanında veya öğün olarak servis yapın. & $\begin{array}{l}\text { You can serve this dish as a light main course or with your } \\
\text { afternoon tea. }{ }^{34}\end{array}$ \\
\hline Beddam Mancar Yemeği & Ugly Beet Dish 35 \\
\hline
\end{tabular}

Tablo 12. Yerlileștirme yöntemi

Tablo 12'de iki örnek görülmektedir. İlk örnekte, kaynak tümcede yer alan "çay" sözcüğü, erek dile "afternoon tea" (ikindi çayı) olarak aktarılmıştır. Çay, Türk kültüründe günün her saatinde tüketilebilen bir içecektir. Kaynak kültür, kahvaltıda, masa başında çalışırken ya da akşam yemeğinden sonra çay içebilir. Ancak özellikle İngiliz kültüründe "ikindi çayı" bir seremoni olarak kabul edilmektedir. "İkindi çayı" kavramının tarihsel bir kökeni vardır. Bu kavram, ilk olarak 1840lı yıllarda Bedford'un yedinci düşesi Anna sayesinde İngiliz kültürüne girmiștir. Düșes, sürekli olarak öğleden sonra saat dört civarında acıkır, ancak akşam yemeği prosedürlere uygun şekilde saat sekizde servis edilmektedir. Düşese göre, öğle ile akşam yemeği arasında uzun bir zaman dilimi bulunmaktadır. Bu nedenle, düşes öğleden sonra odasına çay, ekmek, tereyağı ve kek getirilmesini ister. Bu durum bir alışkanlık haline gelir ve bu seremonide arkadaşları da ona katılır36. Dolayısıyla "ikindi çayı" İngiliz kültüründe, "çay, sandviç ve keklerden oluşan hafif bir yemek" olarak bilinir.

İkinci örnekte yer alan "Beddam Mancar Yemeği" ise, Zonguldak yöresine ait bir yemektir. Yemeğin temel malzemeleri pazı, ısırgan otu, ebe gümeci, kırmızı pancar gibi yöreye özgü otlar ve sebzelerdir. Beddam mancar yemeğinin, yöresel bir yemek olması dolayısıyla, aynı ülke içerisinde olsa bile farklı bölgelerde yaşayan kişiler tarafından çok fazla bilinmediği düşünülebilir. "Beddam", Karadeniz yöresel ağzında "çirkin, kötü" anlamlarında kullanılan bir sözcüktür. Yöresel bir geleneğe göre, ilkbaharda kötülüklerden arınmak için beddam ateşi yakmak ve beddam bitkileri toplamak bir gelenektir. İçerisinde yedi çeşit yeşillik olan bu yemek pişirilip yenilirse hastalıklardan kurtulunacağına ve kötülüklerden arınılacağına inanılır37. "Mancar" ise, Karadeniz bölgesinde yaygın olarak yetișen bir sebzeye verilen addır. Erek metinde söz konusu kültürel referanslara yer verilmediğini, sözcüklerin sözlükte yer alan anlamlarıyla çevrildiğini söyleyebiliriz. Aynı zamanda, iki aşamalı bir çevirinin gerçekleştirildiği tahmin edilebilir. Öncelikle, "beddam" ve "mancar" sözcükleri diliçi çeviri ile "çirkin" ve "pancar" karşllıklarına dönüştürülmüş, daha sonra ise dillerarası çeviri gerçekleştirilmiş̧tir. Bu örnekte yerlileştirme yönteminin benimsendiğini söyleyebiliriz.

Gıda, küresel düzlemde hareket eder. Eğer yerel tatlara dönüştürülür ya da uyarlanırlarsa, bu bir çeşit yerlileştirme olur. Oysa bazen yiyecekler dönüşüme direnir ya da yerel tatlara uyarlandıklarında

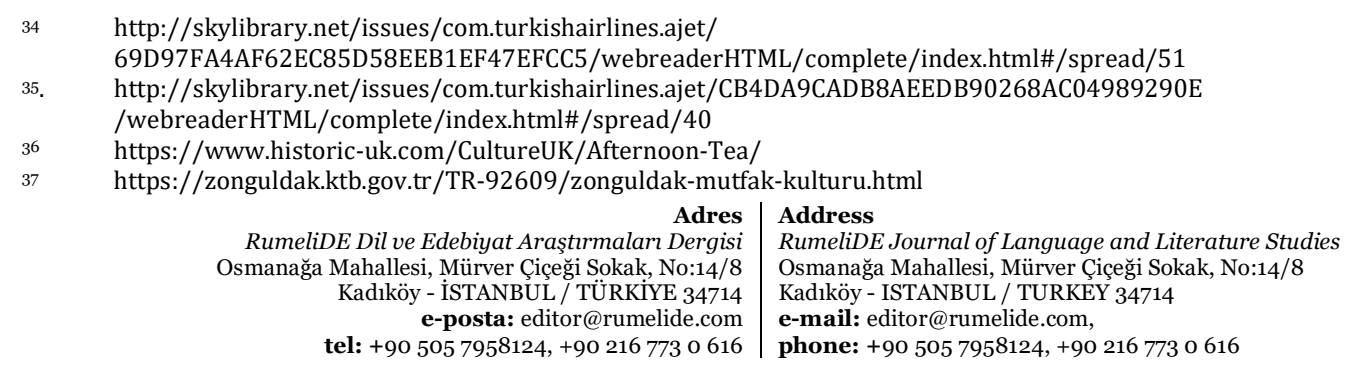


özgünlüklerini yitirebilirler, bu durumda yemekler, teknikler ya da malzemeler bir yabancılaştırma sürecine girer (Desjardins v.d., 2015: 260).

\section{4. Örnek bir inceleme}

Bu çalışma kapsamında yemek tarifi çevirilerinde kullanılan yöntemlere ilişkin örnek bir inceleme yapmak amacıyla, Türk Hava Yolları'nın ticari bir markası olan Anadolu Jet'in 2020 yılı Mart ayında yayın hayatını sonlandıran Anadolu Jet Magazin isimli uçuş dergisinden yemek tarifi metinleri toplanmıştır. Metinlere, derginin web sayfasında bulunan dergi arşivi üzerinden erişilmiştir. Arşivde bulunan dergi makaleleri 2010 yılı Ocak sayısından başlanarak, 2016 yllı Mayıs sayısına kadar taranmış ve yemek tariflerini içeren makaleler belirlenmiştir. Anadolu Jet Magazin dergisi, Türkçe ve İngilizce dillerinde çift dilli olarak yayınlandığı için yemek tarifi içerdiği belirlenen makalenin yine arşiv üzerinden İngilizce paralel metni de belirlenerek ayrılmıştır.

Yemek tarifi barındırdığı belirlenen makaleler içerisinden, yalnızca yemek tariflerinin bulunduğu kısımlar ayıklanarak her bir yemek tarifi ayrı birer metin dosyası șeklinde kaydedilmiştir. Bu şekilde her bir yemek tarifine ait Türkçe ve İngilizce metinleri içeren ikişer metin dosyası hazırlanmıștır. Dosyalar, birbirlerine paralel metinleri içerdiklerini belirtecek şekilde isimlendirilmiștir. Örneğin; 2015 yll Şubat ayında yayınlanan "Anadolu'nun Vazgeçilmez Tadı" 38 isimli makalede "Yoğurtlu Pekmez", "Pekmezli Yumurta" ve "Kestaneli Revani" başlıklı üç ayrı yemek tarifi bulunduğu için bu makaleden üç farklı dosya oluşturulmuş ve Türkçe metinleri içerenler "2015_Subat_1_tr.txt", "2015_Subat_2_tr.txt" ve "2015_Subat_3_tr.txt" şeklinde adlandırılmıştır. Aynı makalenin "Anatolia's Essential Taste" 39 başlıklı İngilizce çevirisini içeren metinden alınan "Yoghurt with Molasses", "Egg with Molasses" ve "Baked Semolina with Chestnut" başlıklı İngilizce yemek tarifleri de "2015_Subat_1_en.txt", "2015_Subat_2_en.txt" ve "2015_Subat_3_en.txt" isimli dosyalar altında kaydedilmiştir.

Hazırlanan bu dosyalar daha sonra bölüm (segment) tabanlı hizalama işlemine tabi tutulmuştur. Bölüm tabanlı hizalama için Farkas Andras tarafından hazırlanmış olan LF Aligner40 isimli açık kaynaklı yazılım kullanılmıştır. $\mathrm{Bu}$ yazılım ile verilen paralel metinlerin bölüm bazlı hizalaması Hunalign ${ }^{41}$ eşleyicisi kullanılarak yapılmaktadır. LF Aligner, otomatik bir eșleme yaptıktan sonra kullanıcıya bölümler üzerinde oluşan hataları da düzeltme olanağı sunmaktadır. Örnek bir bölüm düzenleme ekranı Resim 1'de verilmiştir.

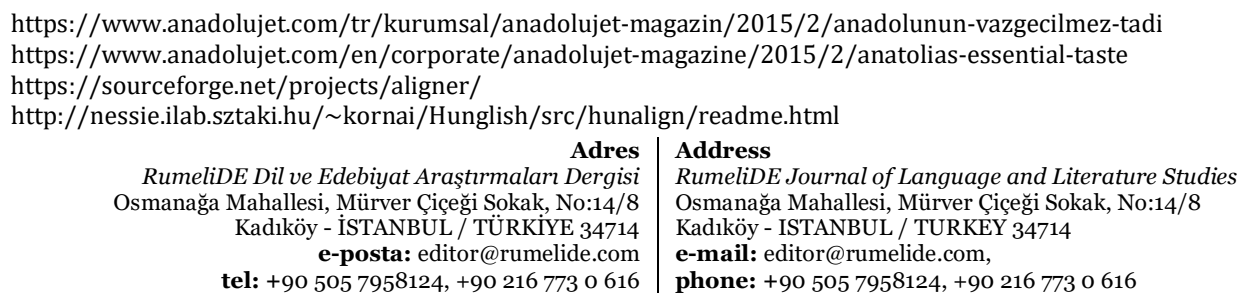




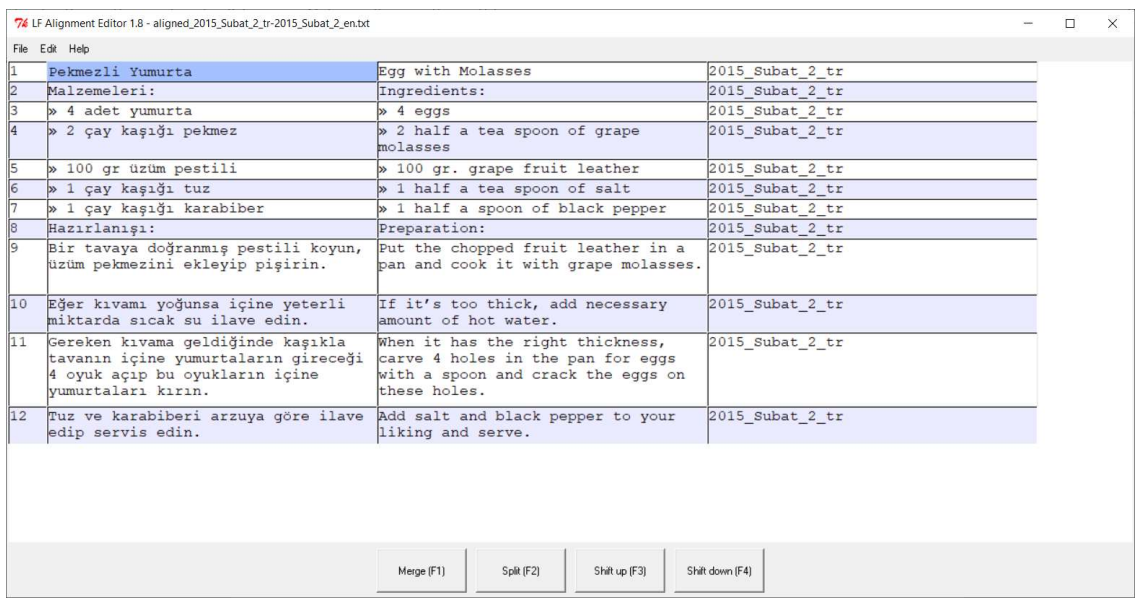

Resim 1. LF Aligner düzenleme ekranı

Bu yöntemle, toplam 244 yemek tarifi paralel bölümler halinde eşleștirilmiştir. Söz konusu yemek tariflerine ait başlıkların (yemek adlarının) çevirileri incelendiğinde en fazla kullanılan yöntemin sözcügü sözcüğüne çeviri olduğu saptanmıştır. Daha sonra da sırasıyla yabancılaştırma, açımlama ve yerlileștirme yöntemlerine başvurulduğu görülmüştür. Stratejilerin birlikte kullanıldığı birimlerin olması nedeniyle Grafik 1'de görülen toplam \%100'ü aşmaktadır. Çoklu stratejilerin kullanımına ilişkin bir örnek de Tablo 13 'te görülebilmektedir.

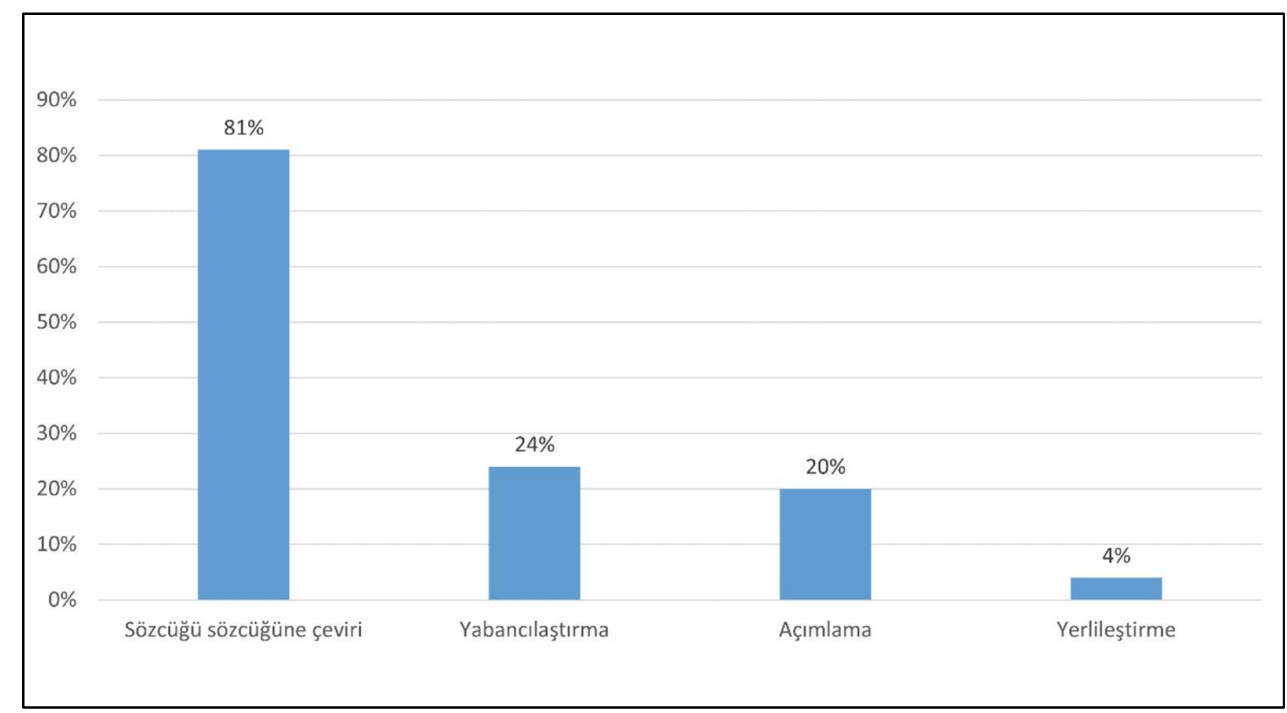

Grafik 1. Yemek adları çevirilerinde kullanılan yöntemler

\begin{tabular}{|l|l|l|}
\hline Türkçe (Kaynak dil) & İngilizce (Erek dil) & Çeviri yöntemi \\
\hline $\begin{array}{l}\text { Mercimekli Kulak } \\
\text { Makarnasi }{ }^{42}\end{array}$ & $\begin{array}{l}\text { Ear-shaped Pasta with Lentil43 (Kulak biçiminde } \\
\text { mercimekli makarna) }\end{array}$ & $\begin{array}{l}\text { Sözcüğü sözcüğüne çeviri, } \\
\text { açımlama }\end{array}$ \\
\hline
\end{tabular}

Tablo 13. Çoklu strateji kullanımı

42 https://www.anadolujet.com/tr/kurumsal/anadolujet-magazin/2016/1/ilgaz-daginin-lezzetleri

43 https://www.anadolujet.com/en/corporate/anadolujet-magazine/2016/1/tastes-from-the-mountain-ilgaz

Adres Address

RumeliDE Dil ve Edebiyat Araşttrmaları Dergisi $\quad$ RumeliDE Journal of Language and Literature Studies

Osmanağa Mahallesi, Mürver Ciçeği Sokak, No:14/8 $\quad$ Osmanağa Mahallesi, Mürver Çiçeği Sokak, No:14/8

Kadıköy - İSTANBUL / TURKIYE 34714 Kadıköy - ISTANBUL / TURKEY 34714

e-posta: editor@rumelide.com $\quad$ e-mail: editor@rumelide.com,

tel: +90 $5057958124,+90216773$ o 616 phone: +90 505 7958124, +90 216773 o 616 


\section{Sonuç}

Yemek tariflerini de kapsayan gastronomi metinleri çevirisi kaynak mutfak kültürünün tanıtımında önemli rol oynar. Yazılı ve sözlü çeviri etkinliğinin gastronomi turizminin bir parçası olduğunu söylemek mümkündür. Gastronomi çevirisi artık çeviri piyasasında özel bir alan olarak kabul edilmekte, birçok çeviri bürosu ve şirketi bu alanda hizmet vermektedir. Gastronomi alanında sürekli olarak, sokak yemeği, organik yemek, yavaş yemek, füzyon mutfağı, moleküler mutfak gibi yeni akımlar ortaya çıkmakta, alanın söz varlığı da gün geçtikçe artmaktadır. Oldukça devingen bir alan olan gastronomide, farklı mutfak kültürleri ve yemekler tüm dünyada dolaşım halindeyken, kültürlerarası iletişimin en önemli unsurlarından biri olan çeviri etkinliğinin bu devinimin dışında kalması beklenemez.

Günümüzde farklı mutfak kültürlerine ait yemek tarifleri gerek basılı gerekse de dijital ortamlarda karşımıza çıkmaktadır. Yemek tarifleri bilgilendirici ve işlemsel metinler olarak kabul edilebilir. Dijital dönüşüm çă̆ıyla birlikte teknolojik gelişmelerin hız kazanması, dünya genelinde internet erişiminin artması gibi nedenlerle, dijital platformlar üzerinden erişilebilen yemek tarifi sayısı da artmıştır. Dijital ortamlarda yayınlanan tarifler çok modlu olarak tasarlanır. Bu metinlerde, sıklıkla dilsel, işitsel ve görsel modlar bir arada bulunur. Çok modlu içerik çevirileri yapılırken, tüm bu bileşenlerin özellikleri gözden kaçırılmamalı; modlar arasındaki etkileşim gözlemlenmeye ve anlaşılmaya çalışılmalıdır. Çok modlu içeriğe sahip bir kaynak metnin çeviri odaklı bir şekilde çözümlenmesi çeviri sürecini kolaylaştıracaktır. Günümüzde, çevirmenin çok modlu çeviri yetkinliğine sahip olması beklenmektedir. Bu da her moda eşit derecede önem verilmesi, dijital okuryazarlık ve araçsal becerilerle ilgilidir.

Yemek tariflerinde yer alan kültüre özgü unsurların, ölçü birimlerinin, pişirme araç ve yöntemlerinin çevirisi, çevirmeni çeviri sürecinde zorlayabilir. Örneğin, kaynak kültürde mevcut olan bir malzeme, erek kültürde bulunamayabilir, bu durumda çevirmen yabancılaştırma yöntemini benimseyerek, kaynak metinde yer alan malzemeyi olduğu gibi bırakabilir, böylece erek metne yerel bir doku da katılmış olur. Aksi halde, çevirmen yerlileștirme yöntemini benimseyebilir, söz konusu malzemenin yerine erek kültürde erişilebilir olan başka bir malzeme koyar, böylece daha erek odaklı bir çeviri gerçekleştirmiş olur. Erek okur, çeviri bir yemek tarifinden ziyade, kendi dilinde kaleme alınmış özgün bir tarif okuyormuş gibi hisseder. Dolayısıyla, erek okurun ortaya lezzetli bir yemek çıkarabilmesi için, malzeme değişikliğine gidilmiş olur. Burada dikkat edilmesi gereken nokta ise benimsenen çeviri yöntemi ya da yöntemlerinin yemek tarifi boyunca istikrarlı bir şekilde uygulanmasıdır.

Bu çalışma kapsamında Türkçe-İngilizce dil çiftinde paralel metinler incelenmiş, yemek tariflerinde yer alan kültüre özgü unsurların çevirisinde hangi çeviri yöntemlerinin sıklıkla kullanıldığı saptanmaya çalışılmıştır. Yemek adlarına ilişkin çevirilerde sözcüğü sözcüğüne çeviri, yabancılaştırma, açımlama ve yerlileştirme yöntemlerinin tercih edildiği görülmüştür. Ayrıca, aynı çeviri birimi için çoklu strateji kullanımının da uygulandığı söylenebilir. Kabul edilebilir bir çeviri üretilmek isteniyorsa, erek kültürün metin geleneklerini bilmek ve uygun yöntemlerden destek almak gerekir.

Özel alan terminolojisi hakkında çevirmenin bilgi sahibi olması önemlidir, metin boyunca terim standardizasyonunun sağlandığından da emin olunması gerekir. Gündelik dilde sıklıkla kullanılan bir sözcük, tariflerde bir gastronomi terimi olarak kullanılabilir. Terimlerin işaret ettiği kavramlar erek ve kaynak dilde tam olarak birbirini karşılamayabilir. Dil kesiti açısından bakıldığında, yemek tariflerinin toplumun tüm kesimlerinden kimseler tarafından rahatlıkla anlaşılabileceği düşünülebilir, ancak tüm tariflerde terminoloji yoğunluğu aynı düzeyde değildir ve okura karmaşık gelebilecek mutfak terimleri,

\footnotetext{
Adres $\mid$ Address

RumeliDE Dil ve Edebiyat Araştırmaları Dergisi $\quad$ RumeliDE Journal of Language and Literature Studies Osmanağa Mahallesi, Mürver Çiçeği Sokak, No:14/8 Osmanağa Mahallesi, Mürver Çiçeği Sokak, No:14/8 Kadıköy - ÍSTANBUL / TÜRKIYE 34714 Kadıköy - ISTANBUL / TURKEY 34714 e-posta: editor@rumelide.com e-mail: editor@rumelide.com, tel: +90 505 7958124, +90 2167730616 phone: +90 505 7958124, +90 2167730616
} 
pişirme yöntemleri ve hazırlama aşamalarını içeren tarifler de vardır. Terminolojik açıdan karmaşı görünen tariflerin çevirilerinde alana özgü dil ve terminoloji bilgisi çevirmene yardımcı olacaktır.

Gastronomiye ilişkin alan bilgisi çevirmenin çeviri sürecinde işini kolaylaştırabilir, aynı zamanda bir içerik üretici ve metin yazarı olan çevirmenin çeviri yönergesine uygun şekilde, gerektiğinde ek açılamalarda bulunması gerekebilir. Başka bir deyişle, genel gastronomi bilgisine sahip olan çevirmenler, yemek tarifi çevirilerinde daha erek odaklı bir yaklaşım belirleyebilirler. Özellikle geleneksel yemeklerin çevirisi söz konusu olduğunda, çevirmenler betimleyici bir yaklaşımla, sürece, tekniklere ve malzemelere ilişkin ek bilgiler verebilir. Bu nedenle, yemek tarifi çevirilerinin disiplinlerarası bir alan olduğu söylenebilir.

\section{Kaynakça}

Aixela, J. F. (1996). Culture-Specific Items in Translation. R. Alvarez, \& C. A. Vidal (Ed.), Translation, Power, Subversion. Frankfurt: Multilingual matters.

Anstey, M., \& Bull, G. (2010). Helping teachers to explore multimodal texts. Curriculum and Leadership Journal, 8(16).

Arola, K. L., Sheppard, J., \&, Ball, C. E. (2014). Writer/ Designer: A Guide to Making Multimodal Projects. Bedford/ St. Martin's.

Brinker, K. (1997). Linguistische Textanalyse, Eine Einführung in Grundbegriffe und Methoden. Berlin: Schmidt.

Coşkun, A. (2021). Explainer: Weird Turkish cooking terms and what they mean. Erişim: https://www.dailysabah.com/life/food/explainer-weird-turkish-cooking-terms-and-what-theymean.

Danesi, M. (Ed.). (2013). Encyclopedia of Media and Communication. University of Toronto Press.

Desjardins, R., Cooke, N., \& Charron, M. (2015). Food and translation on the table: Exploring the relationships between food studies and translation studies in Canada. The Translator, 21(3), 257270.

Epstein, B. J. (2009). What's cooking: translating food. Translation Journal, 13(3).

Eruz, F. S. (1999). Çeviri Eğitiminde ve Çeviride Koşut Metinler: Hukuk Alanında Koşut Metin Çalışmalarının Kapsamı, İşlevleri ve Yöntemleri. İÜ Edebiyat Fakültesi, Sosyal Bilimler Enstitüsü, Alman Dili ve Edebiyatı Anabilim Dalı Doktora Tezi.

Gillespie, C. (2001). European gastronomy into the 21st century. Routledge.

Kerseboom, L. (2010). Cooking and the Art of Translating Recipes (Yüksek Lisans tezi). Hollanda: Utrecht Üniversitesi.

Klenová, D. (2010). The Language of Cookbooks and Recipes (Yüksek Lisans tezi). Çekya: Masaryk Üniversitesi.

Kohler, I. (2011). Translating Food: How to Translate Culture Specific Features in Recipes. Erişim: https://oversattarbloggen.files.wordpress.com/2011/03/essay-2-translating-food.pdf.

Maslow, A. H. (1943). A theory of human motivation. Psychological Review, 50(4), 370-396.

Munday, J. (2008). Introducing Translation Studies: Theories and Applications. New York: Routledge.

Newmark, P. (1988). A textbook of translation. New York: Prentice Hall.

Nord, C. (2005). Text analysis in translation: Theory, methodology, and didactic application of a model for translation-oriented text analysis. Amsterdam/New York: Rodopi.

Özlük, N. (2017). Kullanımlık Metinden (Gebrauchstexte) Edebî Metne veya Edebî Metinden Kullanımlık Metne: İki Şehid-i Aşk. Journal of Strategic Research in Social Science, 3(1), p. 21-30.

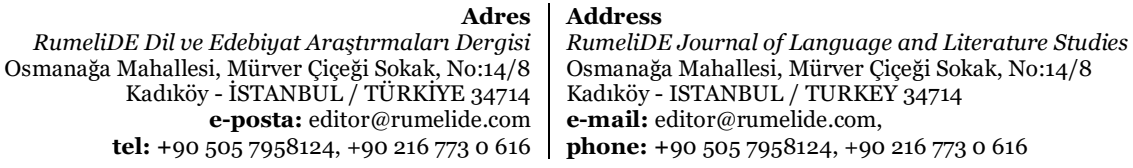


Paradowski, M. B. (2010). Through catering college to the naked chef -teaching LSP and culinary translation. L. Bogucki (ed.). Teaching Translation and Interpreting: Challenges and Practices, 137-165. Newcastle-upon-Tyne: Cambridge Scholars Press.

Pekcoşkun Güner, S. (2021). Conceptualizing Multimodality in the Translation Classroom. Mehmet Cem Odacıŏlu (Ed.), Modern Approaches to Translation Studies, Peter Lang Publishing.

Reiss, K. (2000). Translation criticism- the potentials \& limitations: Categories and criteria for translation quality assessment (E. F. Rhodes, çev.) Manchester: St. Jerome Publishing.

Rolf, E. (1993). Die Funktionen der Gebrauchstextsorten. Berlin/New York: De Gruyter.

Schleiermacher, F. (2004). On the different methods of translating. The translation studies reader, Lawrence Venuti (ed.), 43-63. New York/London: Routledge.

Toklu, O. (2015). Dilbilime Giriş. Ankara: Akçă̆ Yayınları.

Venuti, L. (1995) The Translator's Invisibility. A History of Translation. Routledge, London.

Venuti, L. (1998). The Scandals of Translation: Towards an Ethics of Difference. London / New York: Routledge.

Vinay, J. P., \& Darbelnet, J. (1995). Comparative stylistics of French and English: A methodology for translation. John Benjamins Publishing.

Yazıcı, M. (2005). Çeviribilimin Temel Kavram ve Kuramları, İstanbul: Multilingual.

Yücel Güngör, M. (2020). Gastronominin Temel Kavramları. Hilmi Rafet Yüncü (Ed.), Gastronominin Temelleri, Anadolu Üniversitesi.

RumeliDE Dil ve Edebiyat Araştırmaları Dergisi Osmanağa Mahallesi, Mürver Çiçeği Sokak, No:14/8 Kadıköy - İSTANBUL / TÜRKIYE 34714 e-posta: editor@rumelide.com tel: +90 $5057958124,+902167730616$
Address

RumeliDE Journal of Language and Literature Studies Osmanağa Mahallesi, Mürver Çiçeği Sokak, No:14/8

Kadıköy - ISTANBUL / TURKEY 34714

e-mail: editor@rumelide.com,

phone: +90 5057958124, +90 2167730616 